\title{
KEBERHASILAN USAHA KOPERASI KSPPS BMT BERKAH MANDIRI SEJAHTERA CISARUA BOGOR BERBASIS LINGKUNGAN USAHA DAN PARTISIPASI ANGGOTA
}

\author{
USINESS SUCCESS OF KSPPS BMT BERKAH MANDIRI SEJAHTERA CISARUA \\ BOGOR COOPERATIVE BASED ON BUSINESS ENVIRONMENT AND MEMBER \\ PARTICIPATION
}

\author{
Dwi Gemina $^{1)}$; Erni Yuningsih ${ }^{2)}$; Fitri Catur Andreani ${ }^{3)}$ \\ 1) Universitas Djuanda; ${ }^{2)}$ Universitas Djuanda; ${ }^{3)}$ Universitas Djuanda \\ Correspondence Author: dwigemina@gmail.com
}

\begin{abstract}
This study aims to analyze the effect of the business environment and member participation on the success of the KSPPS BMT Berkah Mandiri Sejahtera cooperative business in Cisarua Bogor. The research object is a cooperative member. Questionnaires were distributed to 100 respondents of cooperative members. The research method used is descriptive and verification. The test used is the validity test, the reliability test. The results of the test data are declared valid and reliable and perform the classical assumption test for use in the regression test. The results showed that simultaneously and partially the business environment and member participation had an effect on the success of the KSPPS BMT Berkah Mandiri Sejahtera cooperative business. Meanwhile, the factors driving the success of the KSPPS BMT Berkah Mandiri Sejahtera cooperative business are the business environment and member participation.
\end{abstract}

Keywords : Economic Environment, Member Participation, The Success Of Cooperative Business

\begin{abstract}
ABSTRAK
Penelitian ini bertujuan untuk menganalisis pengaruh lingkungan usaha dan partisipasi anggota terhadap keberhasilan usaha koperasi KSPPS BMT Berkah Mandiri Sejahtera Di Cisarua Bogor. Objek penelitian adalah anggota koperasi. Koesioner dibagikan kepada 100 responden anggota koperasi. Metode penelitian yang digunakan adalah deskriptif dan verifikatif. Uji yang dilakukan adalah uji validitas, uji reliabilitas, Hasil dari pengujian tersebut data dinyatakan valid dan reliabel serta melakukan uji asumsi klasik untuk digunakan dalam uji regresi. Hasil penelitian bahwa secara simultan dan parsial lingkungan usaha dan partisipasi anggota berpengaruh terhadap keberhasilan usaha koperasi KSPPS BMT Berkah Mandiri Sejahtera. Sedangkan factor pendorong keberhasilan usaha koperasi KSPPS BMT Berkah Mandiri Sejahtera adalah lingkungan usaha dan partisipasi anggota.
\end{abstract}

Kata Kunci : Lingkungan Usaha, Partisipasi Anggota, Keberhasilan Usaha 


\section{PENDAHULUAN}

Koperasi merupakan organisasi masyarakat yang berperan penting bagi sumberdaya dan kepentingan pembangunan, oleh karena itu koperasi diharapkan sebagai soko guru perekonomian nasional Indonesia mengalami pertumbuhan yang sangat pesat. Atas dasar tersebut, koperasi sebagai organisasi ekonomi dan sosial berusaha meningkatkan kesejahteraan para anggota dan masyarakat sekitarnya, dan memberikan sumbangan mendasar kepada pembangunan dan pertumbuhan sosial ekonomi, karena itu, keberhasilan koperasi sangat penting bagi laju pertumbuhan ekonomi bangsa Indonesia.

Permasalahan yang timbul berkaitan dengan lingkungan usaha yaitu: banyaknya anggota yang tidak mau bekerja sama dan tingkat pengambilan pinjaman yang amat lama atau kredit macet. Sehingga koperasi mengalami hambatan dalam pembayaran dan hal ini mempengaruhi pendapatan usaha koperasi. Permasalahan lain yang timbul dikarnakan perusahaan koperasi memiliki keterbatasan atau kekurangan sumber daya manusia seperti kekurangan karyawan dan keterampilan pemasaran, budaya kerja yang masih rendah sehingga dalam pelayanan kurang optimal, dalam hal ini berdampak terhadap penurunan anggota koperasi, penurunan kepercayaan anggota koperasi yang berdampak kepada penurunan keanggotaan koperasi, dan pergeseran permintaan konsumen atau anggota. Bisa dilihat dari tabel keragaan koperasi KSPPS BMT Berkah Mandiri Sejahtera dalam kurun waktu lima tahun terakhir.

Tabel 1. Keragaan Koperasi KSPPS BMT Berkah Mandiri Sejahtera

\begin{tabular}{ccccccrr}
\hline No & Tahun & $\begin{array}{c}\text { Jumlah Anggota } \\
\text { (Orang) }\end{array}$ & $\begin{array}{c}\text { Jumlah Modal } \\
\text { Sendiri (Rp) }\end{array}$ & $\begin{array}{c}\text { Jumlah } \\
\text { Modal Luar } \\
(\mathbf{R p})\end{array}$ & $\begin{array}{c}\text { Jumlah Aset } \\
(\mathbf{R p})\end{array}$ & $\begin{array}{c}\text { Volume Usaha } \\
(\mathbf{R p})\end{array}$ & $\begin{array}{c}\text { Jumlah SHU } \\
(\mathbf{R p})\end{array}$ \\
\hline 1 & 2013 & 830 & 1.274 .957 .661 & 1.945 .366 .323 & 4.627 .833 .345 & 3.814 .276 .364 & $60.218 .640,51$ \\
2 & 2014 & 969 & 1.461 .863 .324 & 2.124 .445 .332 & 4.522 .099 .322 & 4.755 .681 .712 & $104.340 .710,84$ \\
3 & 2015 & 1.134 & 1.631 .360 .134 & 2.278 .564 .505 & 4.823 .224 .542 & 3.613 .447 .647 & $48.116 .649,43$ \\
4 & 2016 & 1.282 & 1.116 .354 .321 & 2.476 .344 .338 & 5.234 .770 .504 & 4.825 .300 .406 & $187.029 .523,14$ \\
5 & 2017 & 1.381 & 2.281 .654 .228 & 2.521 .233 .323 & 5.245 .899 .003 & 4.235 .422 .694 & $148.893 .489,16$ \\
\hline
\end{tabular}

Pada Tabel 1 tersebut menunjukan keragaan KSPPS BMT Berkah Mandiri Sejahtera dengan jumlah anggota terendah terjadi pada tahun 2013 yaitu sebanyak 830 anggota, jumlah modal sendiri dalam nominal terendah terjadi pada tahun 2016 sebesar Rp1.116.354.321, jumlah modal yang berasal dari luar dalam nominal terendah terjadi pada tahun 2013 sebesar Rp1.945.366.323, jumlah aset terendah terjadi pada tahun 2014 sebesar Rp4.522.099.322, jumlah volume usaha dalam nominal terendah pada tahun 2015 sebesar Rp 3.613.447.647, dan jumlah perolehan SHU terendah terjadi pada tahun 2015 dengan nominal sebesar Rp48.116.649,43 sehingga perkembangan keragaan yang berada di KSPPS BMT Berkah Mandiri Sejahtera mengalami fluktuatif setiap tahunya.

Berdasarkan laporan Dewan Pengawas Koperasi KSPPS BMT Berkah Mandiri Sejahtera Tahun 2017 dalam hal partisipasi anggota menunjukkan masih rendah dalam keaktifan. Berikut ini data keaktifan anggota Koperasi KSPPS BMT Berkah Mandiri Sejahtera dalam kurun lima tahun terakhir. 
Tabel 2. Data Keaktifan Anggota Koperasi KSPPS BMT Berkah Mandiri Sejahtera

\begin{tabular}{cccc}
\hline Tahun & $\begin{array}{c}\text { Jumlah } \\
\text { Anggota }\end{array}$ & $\begin{array}{c}\text { Keaktifan } \\
\text { Anggota }\end{array}$ & $\begin{array}{c}\text { Prosentase (\%) } \\
\text { Aktifan Anggota }\end{array}$ \\
\hline 2013 & 830 & 664 & 80 \\
2014 & 969 & 921 & 96 \\
2015 & 1.134 & 850 & 75 \\
2016 & 1.282 & 833 & 65 \\
2017 & 1.381 & 691 & 50 \\
\hline
\end{tabular}

Sumber: Laporan RAT Koperasi KSPPS BMT Berkah Mandiri Sejahtera, 2018

Tabel 2 menunjukan bahwa keaktifan anggota tidak sesuai dengan jumlah anggota. Keaktifan anggota cenderung mangalami fluktuasi setiap tahunnya. Berdasarkan tabel tersebut selama tahun 2014-2017 jumlah keaktifan anggota koperasi mengalami penurunan. Data terendah adalah pada tahun 2017 sebesar 50 persen dari total anggota 1.381 orang dan jumlah keaktifan anggota yang mengalami tingkat keaktifan yang tinggi diperoleh pada tahun 2014 dengan prosentase 96 persen dari total anggota yang aktif.
Penurunan anggota koperasi disebabkan karena kurangnya sosialisasi tentang keuntungan koperasi bagi anggota, keterbatasanya pengetahuan anggota terhadap pembagian SHU dan kurangnya pengetahuan anggota terhadap manfaat dari koperasi. Laporan RAT Koperasi KSPPS BMT Berkah Mandiri Sejahtera dalam kurun waktu lima tahun terakhir. Berikut ini data perolehan SHU dalam kurun waktu lima tahun terakhir di Koperasi KSPPS BMT Berkah Mandiri Sejahtera.

Tabel 3. Perolehan SHU Koperasi KSPPS BMT Berkah Mandiri Sejahtera

\begin{tabular}{ccccc}
\hline Tahun & Perolehan SHU & Target & Persentase (\%) & Keterangan \\
\hline 2013 & Rp 60.218.640,51 & Rp 36.204.499,96 & 166 & Tercapai \\
2014 & Rp 104.340.710,84 & Rp 75.393.661,86 & 138 & Tercapai \\
2015 & Rp 48.116.649,43 & Rp 170.133.442,16 & 28 & Tidak tercapai \\
2016 & Rp 187.029.523,14 & Rp 267.434.760,33 & 70 & Tidak tercapai \\
2017 & Rp 148.893.489,16 & Rp 223.623.030,70 & 67 & Tidak tercapai \\
\hline
\end{tabular}

Sumber: Laporan RAT Koperasi KSPPS BMT Berkah Mandiri Sejahtera, 2018

Tabel 3 menunjukkan bahwa perolehan SHU dari tahun 2013-2017 mengalami penurunan. Tingkat penurunan SHU terendah dialami pada tahun 2015 dengan total SHU Rp48.116.649,43, dengan persentase 28 persen. Akan tetapi, pertumbuhan SHU koperasi KSPPS BMT Berkah Mandiri Sejahtera mengalami kenaikan pada tahun 2016 dengan sebesar Rp267.434.760,33. Setiap tahunnya perusahaan koperasi mengevaluasi naik turunnya target namun masih tetap target yang ditentukan tidak tercapai. Hal ini perlu menjadi perhatian serius bagi pengurus Koperasi KSPPS BMT Berkah
Mandiri Sejahtera dalam mengatasi permasalahan tersebut. Oleh sebab itu belum optimalnya lingkungan usaha dan partisipasi anggota sehingga keberhasian koperasi menurun.

\section{MATERI DAN METODE}

\section{Manajemen Sumber Daya Manusia (MSDM) \\ Menurut Mangkunegara (2011:2) MSDM adalah suatu perencanaan, pengorganisasian, pengarahan dan pengawasan kegiatan-kegiatan pengadaan}


pengembangan, pemberian kompensasi, pengintegrasian, pemeliharaan dan pelepasan sumber daya manusia agar tercapai berbagai tujuan individu, organisasi dan masyarakat.

\section{Lingkungan Usaha}

Menurut Suryana (2006: 109), lingkungan usaha merupakan kondisi usaha yang dapat menjadi pendorong maupun penghambat jalannya suatu perusahaan. Lingkungan yang dapat mempengaruhi jalannya usaha atau perusahaan adalah lingkungan internal dan lingkungan ekternal. Menutut Darwin (2008:45) bahwa lingkungan usaha digolongkan menjadi dua yaitu: 1) Lingkungan makro (lingkungan eksternal) yaitu pendapatan para anggota; 2) Lingkungan mikro (lingkungan internal) terdiri dari: lembaga keuangan dan badan usaha.

\section{Partisipasi Anggota}

Menurut Hendar dan Kusnadi (2005:89) partisipasi adalah suatu aktivitas untuk membangkitkanperasaan diikutsertakan dalam kegiatan organisasi dan ikut sertanya bahwa dalam kegiatan organisasi sehingga keterlibatan mental dan emosional dari anggota koperasi dalam memberikan inisiatif terhadap kegiatan yang dilakukan koperasi dalam rangka mencapai tujuan koperasi. Menurut Hendar dan Kusnandi (2005:94) bahwa indikator partisipasi anggota yaitu:

1) Keikutsertaan dalam perencanaan koperasi;

2) Keikutsertaan dalam organisasi;

3) Keikutsertaan dalam permodalan koperasi;

4) Keikutsertaan dalam usaha koperasi;

5) Keikutsertaan dalam pengawasan koperasi.

\section{Keberhasilan Usaha Koperasi}

Menurut Any Meilani dan Sri Ismulyaty (2002:13), keberhasilan koperasi merupakan prestasi dalam melaksanakan kegiatan berbisnis dalam meningkatkan kesejahteraan anggotanya dan masyarakat pada umumnya. Keberhasilan pengelolaan koperasi tersebut dapat dicapai karena dilaksanakan dengan manajemen yang baik. Menurut Hanel
(2005:270) bahwa keberhasilan yaitu: 1) Efisiensi pengelolaan usaha; 2) Efisiensi pembangunan; 3) Efisiensi anggota.

\section{Pengembangan Hipotesis}

Manajemen adalah ilmu dan seni mengatur proses pemanfaatan sumber daya manusia dan sumber-sumber lainnya secara efektif dan efisien untuk mencapai suatu tujuan tertentu Hasibuan (2014:23). Lingkungan usaha sangatlah mempengaruh sebuah keberhasilan dalam usaha atau perusahaan maka dari itu lingkungan sangat penting untuk menentukan keberhasilan. Menurut Suryana (2003: 75), lingkungan usaha merupakan kondisi usaha yang dapat menjadi pendorong maupun penghambat jalannya suatu perusahaan.

Partisipasi anggota merupakan peran penting dalam menetukan suatu keberhasilan, tanpa adanya peran anggota koperasi tidak akan mampu untuk maju, maka partisipasi anggota sangat penting bagi pertumbuhan koperasi dan pembangunan guna mencai tujuan meningkatkan kesejahteraan. Menurut Anoraga dan Nanik (2003:25) partisipasi anggota merupakan kesediaan anggota itu untuk memikul kewajiban dan menjalankan hak keanggotaanya secara bertanggung jawab, maka partisipasi anggota koperasi yang bersangkutan sudah dikatakan baik.

Koperasi dalam menjalankan kegiatanya sangat bergantung terhadap lingkungan yang ada diluar maupun yang ada didalam perusahaan. Faktor yang mempengaruhi keberhasilan koperasi diantaranya partisipasi anggota dan lingkungan usaha. Melalui partisipasi anggota, koperasi dapat menggerakkan sumber-sumber daya yang ada untuk mencapai tujuannya. Menurut Hatta dalam Gemina (2017: 34) menyatakan yang bekerja adalah semua anggota dan sama bertanggung jawab atas keselamatan koperasi. Hal ini seperti yang dikemukakan oleh Khasan Setiaji (2009) ada pengaruh signifikan antara partisipasi anggota terhadap keberhasilan dan 
ada pengaruh signifikan antara lingkungan usaha terhadap keberhasilan serta ada pengaruh signifikan antara partisipasi anggota dan lingkungan usaha terhadap keberhasilan. Dari pendapat dan hasil riset diatas, maka hipotesisnya adalah: 1) Lingkungan usaha dan partisipasi anggota berpengaruh secara positif dan signifikan terhadap keberhasilan usaha koperasi $\left(\mathrm{H}_{1}\right)$; 2) Lingkungan usaha berpengaruh secara positif dan signifikan terhadap keberhasilan usaha koperasi $\left.\left(\mathrm{H}_{2}\right) ; 3\right)$ Partisipasi anggota berpengaruh secara positif dan signifikan terhadap keberhasilan usaha koperasi $\left(\mathrm{H}_{3}\right)$.

\section{Kerangka Pemikiran}

Gambar berikut memperlihatkan kerangka pemikiran dari penelitian ini:

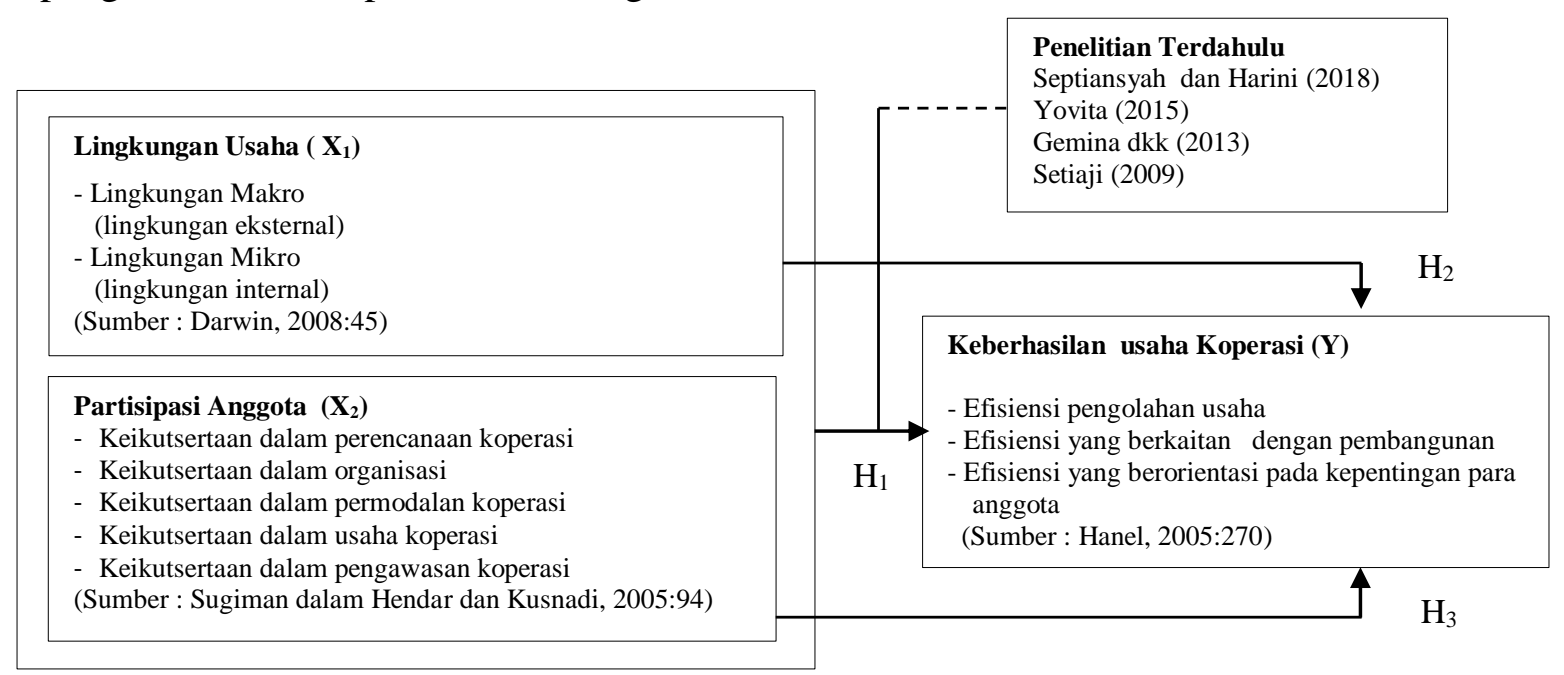

\section{Metode Penelitian}

Objek pada penelitian ini adalah Koperasi KSPPS BMT Berkah Mandiri Sejahtera Cisarua. Adapun lokasi penelitian yang dipilih dalam penelitian ini adalah KSPPS BMT Berkah Mandiri Sejahtera yang beralamat di Jalan Citeko Pasar Cisarua Blok C No 11 A Bogor sebanyak 1.381 orang anggota. Teknik pengambilan sampel yang digunakan dalam penelitian ini adalah teknik purposive sampling. Adapun teknik pengambilan sampel yang dilakukan untuk menentukan sampel penelitian dengan beberapa pertimbangan tertentu yang bertujuan agar data yang diperoleh nantinya bisa lebih representatif, untuk menentukan sampel penelitian ini akan menggunakan rumus Slovin

\section{Pemikiran}

yang didapatkan dari Husein Umar (2007) yaitu sebagai berikut :

$$
n=\frac{N}{1+N e^{2}} \quad \frac{381}{31 \times 0.1^{2}}
$$

Keterangan :

$\mathrm{n}$ : Jumlah sampel;

$\mathrm{N}$ : Jumlah populasi;

e : Tingkat kesalahan (error level), pada umumnya dan sering digunakan untuk tingkat kesalahan menggunakan $10 \%$.

Jadi untuk sampel atau responden yang akan digunakan dalam penelitian ini sebanyak 100 orang anggota. Penelitian memakai metode deskriptif juga verifikatif diperoleh pemilahan data lingkungan usaha dan partispiasi anggota dan keberhasilan Koperasi, penelitian ini 
menggunakan data primer didapat penyebaran kuesioner. Data lain dipakai data sekunder dan diolah data primer itu sendiri. Pengujian data menggunakan uji validitas, reliabilitas. Setelah semua instrument diuji, selanjutnya dilakukan regresi linear berganda, korelasi berganda, koefisien determinasi, pengujian hipotesis secara simultan (Uji F) dan terakhir adalah pengujian secara parsial (Uji t). Adapun operasionalisasi variabel pada peelitian ini, dapat dijelaskan pada tabel sebagai berikut:

Tabel 4. Operasionalisasi Variabel

\begin{tabular}{|c|c|c|c|}
\hline Variabel & Konsep Variabel & Indikator & Skala Ukuran \\
\hline $\begin{array}{l}\text { Lingkungan } \\
\text { Usaha }\left(\mathrm{X}_{1}\right)\end{array}$ & $\begin{array}{l}\text { Keadaan atau kondisi yang dapat } \\
\text { mempengaruhi perkembangan usaha } \\
\text { koperasi baik dari lingkungan koperasi } \\
\text { secara keseluruhan (makro) maupun dari } \\
\text { lingkungan koperasi secara langsung } \\
\text { (mikro) yang merupakan peluang dan } \\
\text { ancaman bagi perusahaan koperasi. } \\
\text { (Sumber Darwin 2008:45) }\end{array}$ & $\begin{array}{l}\text { A. Lingkungan Makro } \\
\text { (lingkungan eksternal) } \\
\text { Pendapatan para anggota } \\
\quad \text { (koperasi) } \\
\text { B. Lingkungan Mikro } \\
\quad \text { (lingkungan internal) } \\
\text { a. Lembaga keuangan } \\
\text { b. Badan usaha }\end{array}$ & Ordinal \\
\hline $\begin{array}{l}\text { Partisipasi Anggota } \\
\left(\mathrm{X}_{2}\right)\end{array}$ & $\begin{array}{l}\text { Suatu aktivitas untuk membangkitkan } \\
\text { perasaan diikutsertakan dalam kegiatan } \\
\text { organisasi dan ikut serta bahwa dalam } \\
\text { kegiatan organisasi. } \\
\text { (Sumber: Hendar dan Kusnandi 2005:89) }\end{array}$ & 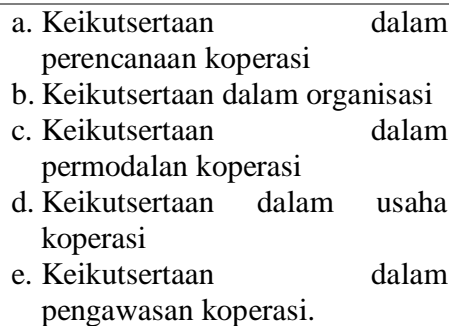 & Ordinal \\
\hline $\begin{array}{l}\text { Keberhasilan Usaha } \\
\text { Koperasi } \\
\text { (Y) }\end{array}$ & $\begin{array}{l}\text { Merupakan prestasi dalam melaksanakan } \\
\text { kegiatan berbisnis dalam meningkatkan } \\
\text { kesejahteraan anggotanya dan masyarakat } \\
\text { pada umumnya. } \\
\text { Hanel dalam (Yuliani 2007: 17) }\end{array}$ & $\begin{array}{l}\text { a. Efisiensi pengelolaan usaha } \\
\text { b. Efisiensi pembangunan } \\
\text { c. Efisiensi anggota }\end{array}$ & Ordinal \\
\hline
\end{tabular}

\section{HASIL DAN PEMBAHASAN}

\section{Karakteristik Rekapitulasi Anggota Koperasi}

Berdasarkan data diperoleh bahwa mayoritas anggota koperasi berjenis kelamin perempuan sebesar 60 persen karena sebagai ibu rumah tangga dan memiliki kemampuan berorganisasi serta mengelola keuangan keluarga, berusia antara 23-29 tahun sebesar 30 persen anggota koperasi mempunyai anggota dengan usia yang masih produktif, dengan berstatus sudah menikah sebesar 77 persen, dengan latar belakang pendidikan
SMA - Sederajat sebesar 63 persen dan memiliki lamanya masa anggota 5-6 tahun sebesar 34 persen. Pekerjaan anggota yaitu pedagang pasar sebesar 70 persen. Sedangkan penghasilan anggota setiap bulanya sebesar Rp1,5- Rp2,5 juta sebesar 32 persen sehingga dapat memenuhi kebutuhan dan berbagai tanggungjawab dengan suami dalam mengurus kebutuhan rumah tangga dan anak. Adapun hasil rekapitulasi tanggapan anggota koperasi mengenai lingkungan ekonomi, partisipasi anggota dan keberhasilan usaha koperasi berikut ini: 


\section{Tanggapan Anggota Koperasi}

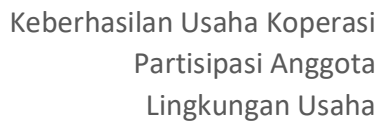

Gambar 2. Rekapitulasi Tanggapan Anggota Koperasi Terhadap Lingkungan Usaha, Partisipasi Anggota dan Keberhasilan Usahan Koperasi

Sumber: Hasil Data Primer, 2019

Rata-rata tanggapan anggota koperasi terhadap lingkungan usaha sebesar 79 persen bahwa setuju anggota merasa dengan adanya koperasi membantu memperbaiki ekonomi masyarakat sekitar dan lebih baik dalam bersosialisasi untuk kemajuan dan mensejahterakan para anggota, rata-rata tanggapan anggota koperasi terhadap partisipasi anggota sebesar 78 persen bahwa setuju memiliki lingkungan usha yang baik sehingga anggota koperasi memperoleh kemudahan dalam proses pelayanan. Anggota merasa nyaman untuk tetap bertahan dikoperasi karena pelayanan yang diberikan anggota sangat baik dan mudah dipahami sehingga mudah mengakses informasi mengenai KSPPS BMT Berkah Mandiri Sejahtera. Anggota selalu ikut dilibatkan dalam penyampaian pendapat dan aktif dalam menyampaikan saran diforum yang telah ditetapkan. Sedangkan rata-rata tanggapan anggota koperasi terhadap keberhasilan usaha sebesar 78 persen setuju memberikan jasa pelayanan yang meningkatkan usaha ekonomi para anggotanya. Pelayanan merupakan tindakan atau kegiatan yang dapat ditawarkan pihak koperasi kepada anggotanya, mengutamakan kenyamanan keamanan para anggota dan akan memberikan infomasi yang baik dan berguna bagi anggota.

\section{Uji Validitas dan Reliabilitas Instrumen Penelitian}

Uji validitas dilakukan dengan tujuan mengukur pernyataan atau pertanyaan dalam kuesioner. Validitas sebuah data dinyatakan terpenuhi jika pernyataan atau pertanyaan itu bisa ungkap sesuatu. Berdasarkan pengujian instrumen menunjukkan bahwa uji validitas terkait variabel bebas lingkungan usaha dan partisipasi anggota dan variabel terikat yakni keberhasilan usaha koperasi dikatakan valid, dapat dilanjutkan ke pengujian reliabilitas.

Uji reliabilitas ialah alat pengukur kuesioner semua indikator variabel, instrumen yang reliabel berarti instrumen yang bila digunakan berapa kali untuk mengukur objek yang sama akan menghasilkan data yang sama (Sugiyono, 2016:121). Berdasarkan pengujian instrument penelitian menunjukkan bahwa uji validitas terkait variabel bebas lingkungan usaha dan partisipasi anggota dan variabel terikat yakni keberhasilan usaha koperasi diperoleh hasil jika seluruh item reliabel karena memiliki Cronbach Alpha > 0,6.

\section{Uji Asumsi Klasik}

Hasil uji yaitu a) Uji normalitas bahwa data dinyatakan terdistribusi normal; b) Uji multikolonieritas tidak multikoloni antara variabel bebasnya; c) Uji heterokedastisitas tidak heterokedastisitas dari semua model 
regresi sehingga semua model regresi dapat dilanjutkan ke uji regresi linear berganda.

\section{Rangkuman Hasil Perhitungan Analisis Regresi Berganda Model Penelitian}

Analisis regresi berganda digunakan untuk meramalkan bagaimana keadaan (naik turunya) variabel dependen, bila dua atau lebih variabel independen sebagai faktor prediktor sehingga dapat diketahui ada atau tidaknya pengaruh variabel bebas terhadap variabel berikut. berdasarkan hasil perhitungan data menggunakan SPSS 22 pada tabel berikut ini :

\begin{tabular}{|c|c|c|c|c|c|}
\hline \multirow{3}{*}{ Model } & Usah & erasi $\mathbf{K S}$ & MT Berkah & adiri & itera \\
\hline & \multicolumn{2}{|c|}{$\begin{array}{l}\text { Unstandardized } \\
\text { Coefficients }\end{array}$} & \multirow{2}{*}{$\begin{array}{l}\text { Standardized } \\
\text { Coefficients } \\
\text { Beta }\end{array}$} & \multirow[t]{2}{*}{$\mathbf{T}$} & \multirow[t]{2}{*}{ Sig. } \\
\hline & B & Std. Error & & & \\
\hline (Constant) & 3,691 & 3,201 & & 1.153 & .252 \\
\hline Lingkungan Usaha $\left(\mathrm{X}_{1}\right)$ & .412 & .077 & .461 & 6.069 & .000 \\
\hline Partisipasi Anggota $\left(\mathrm{X}_{2}\right)$ & .263 & .043 & .405 & 5.357 & .000 \\
\hline $\mathrm{t}$-tabel & $=1,661$ & & & & \\
\hline F-hitung & $=51.450$ & & & & \\
\hline Sig & $=0,000$ & & & & \\
\hline F-tabel & $=3,09$ & & & & \\
\hline $\mathrm{R}$ & $=, 717$ & & & & \\
\hline $\mathrm{R}^{2}$ & $=, 515$ & & & & \\
\hline Adjusted $\mathrm{R}^{2}$ & $=, 505$ & & & & \\
\hline Alpha $(\alpha)$ & $=0,05$ & & & & \\
\hline SEE & $=2,619$ & & & & \\
\hline
\end{tabular}

Sumber: Data Diolah, 2019

Berdasarkan tabel rangkuman hasil perhitungan statistik diperoleh nilai $\mathrm{R}$ atau korelasi sebesar 0,717 yang berada pada kategori kuat dan positif, hal ini menunjukkan bahwa antara lingkungan usaha dan partisipasi anggota dengan keberhasilan usaha koperasi KSPPS BMT Berkah Mandiri Sejahtera semakin kuat. Sedangkan hasil $R$ Square sebesar 0,515, hal ini menunjukkan bahwa persentase sumbangan pengaruh variabel kepercayaan konsumen, keamanan dan persepsi risiko terhadap keputusan pembelian sebesar 52 persen. Sedangkan sisanya 48 persen dipengaruhi oleh faktor lain yaitu pelayanan, permodalan, pembinaan pemerintah dan kompetensi manajer (Ropke, 2003:17).

\section{Pengaruh Lingkungan Usaha dan Partisipasi Anggota Terhadap Keberhasilan Usaha Koperasi KSPPS BMT Berkah Mandiri Sejahtera}

Hasil uji secara simultan dengan nilai Fhitung sebesar 51,450 dan nilai Ftabel, untuk $0,05(\alpha=5$ persen $)$ dan derajat kebebsan $\mathrm{V}_{1}=3-1=2$ dan $\mathrm{V}_{2}=100-2-1=97$ sebesar 3,09 yang dimana bisa dilihat bahwa Fhitung lebih besar dari Ftabel (51,450 > 3,09) maka dapat disimpulakan bahwa Ho ditolak dan Ha diterima, yang artinya dengan tingkat kepercayaan 95 persen variabel independen lingkungan usaha dan partisipasi anggota berpengaruh positif dan signifikan secara simultan (bersama-sama) terhadap keberhasilan usaha koperasi koperasi KSPPS BMT Berkah Mandiri Sejahtera. Khoriyah (2016) bahwa keberhasilan organisasi koperasi sangat ditentukan oleh partisipasi anggota dalam mengikuti kegiatan-kegiatan 
serta usaha-usaha yang ada dikoperasi tidak terlepas dari aktifitnya partisiapsi anggota dalam memanfaatkan usaha yang ada dikoperasi. Keberhasilan usaha koperasi dikarenakan anggota menyadari seutuhnya keberadaan koperasi dalam membantu mensejahterakan para anggotanya.

\section{Pengaruh Lingkungan Usaha Terhadap Keberhasilan Usaha Koperasi KSPPS BMT Berkah Mandiri Sejahtera}

Hasil uji secara parsial dengan nilai thitung pada variabel lingkungan usaha sebesar 6,069 dan nilai Ttabel dengan tingkat $0,05(\alpha=5 \%)$ dengan derajat kebebasan 1002-1=97 didapatkan nilai sebesar 1,661 berarti thitung lebih besar dari tabel (thitung > ttabel) sebesar $(6,069>1,661)$, hal ini dapat dilihat dari nilai koefisien korelasi 0,412 serta memiliki nilai signifikansi sebesar dengan nilai sigifikan $0,000<0,05$ maka Ho ditolak Ha diterima artinya secara parsial faktor lingkungan usaha dan partisipasi anggota berpengaruh positif dan signifikan terhadap keberhasilan usaha koperasi KSPPS BMT Berkah Mandiri Sejahtera. Ada pengaruh lingkungan usaha terhadap keberhasilan usaha Koperasi (Etika Sari Sulistyorini. 2015).

\section{Pengaruh Partisipasi Anggota Terhadap Keberhasilan Usaha Koperasi KSPPS BMT Berkah Mandiri Sejahtera}

Hasil uji secara parsial dengan nilai thitung pada variabel partisipasi anggota sebesar 5.357 nilai tabel dengan tingkat $\alpha=$ 0,05 dengan derajat kebebasan 100-2-1=97 didapatkan nilai sebesar 1,661. Hal ini menunjukkan bahwa thitung lebih besar dari tabel (thitung > ttabel) sebesar (5,357> 1,661). Hal ini dapat dilihat dari nilai koefisien kolerasi 0,263 dengan nilai signifikan $0,000<0,05$ maka Ho ditolak dan $\mathrm{Ha}_{\mathrm{a}}$ diterima artinya partisipasi anggota berpengaruh positif dan signifikan terhadap keberhasilan usaha koperasi pada koperasi
KSPPS BMT Berkah Mandiri Sejahtera. Faktor partisipasi anggota dengan keberhasilan usaha memiliki korelasi yang tinggi, baik langsung maupun tidak langsung. Kondisi tersebut sejalan dengan peranan partisipasi anggota bagi keberhasilan usaha. Partisipasi aktif anggota akan membantu lancarnya usaha koperasi (Ketut Rantau. 2002).

Faktor pendorong keberhasilan usaha koperasi KSPPS BMT Berkah Mandiri Sejahtera adalah lingkungan usaha dan partisipasi anggota.

\section{KESIMPULAN DAN IMPLIKASI}

Berdasarkan hasil penelitian mengenai pengaruh lingkungan usaha dan partisipasi anggota terhadap keberhasilan usaha koperasi KSPSS BMT Berkah Mandiri Sejahtera maka didapatkan beberapa kesimpulan sebagai berikut : 1) Tanggapan anggota koperasi terhadap lingkungan usaha, partisipasi anggota dan keberhasilan usaha koperasi KSPPS BMT Berkah Mandiri Sejahtera termasuk dalam kategori baik; 2) Hasil pengujian secara simultan dan parsial, lingkungan usaha dan partisipasi anggota berpengaruh positif dan signifikan terhadap keberhasilan usaha koperasi KSPPS BMT Berkah Mandiri Sejahtera. Sehingga factor pendorong keberhasilan usaha koperasi KSPPS BMT Berkah Mandiri Sejahtera adalah lingkungan usaha dan partisipasi anggota.

Sedangkan implikasi diantaranya: 1) Perlunya peningkatan kualitas kehidupan anggota koperasi, memberikan saran-saran kepada pengurus dalam hal pengelolan koperasi serta efisiensi pembangunan yang diberikan koperasi harus memberikan keuntungan bagi anggota. karena akan berpengaruh terhadap keberhasilan koperasi; 2) Lingkungan usaha dan partisipasi anggota yang itemnya memiliki nilai terendah agar terus diperbaiki, dievaluasi dan ditingkatkan 
seperti lembaga keuangan koperasi memudahkan para anggotanya, serta Memberikan saran - saran kepada pengurus dan efisiensi pembangunan yang diberikan koperasi memberikan keuntungan anggota, sehingga dapat meningkatkan keberhasilan koperasi 3) Bagi peneliti selanjutnya menambah pelayanan, permodalan, pembinaan pemerintah dan kompetensi manajer sehingga hasilnya lebih sempurna.

\section{UCAPAN TERIMAKASIH}

Terimakasih kepada semua pihak yang sudah berkontribusi dalam penelitian ini sehingga dapat terlaksana dengan baik.

\section{DAFTAR PUSTAKA}

Anoraga, Nanik. 2003. Dinamika Koperasi. Jakarta: Rineka Cipta.

Darwin. 2008. Manajemen Perusahaan. Jakarta: FKIP Universitas Lampung.

Dessler, Gerry. 2011. Manajemen Sumber Daya Manusia. Jilid 1. Jakarta: PT. Indeks Kelompok. Gramedia.

Etika Sari Sulistyorini. 2015. Pengaruh Partisipasi Anggota, Lingkungan Usaha, Kualitas Pelayanan, Dan Kinerja Karyawan Terhadap Keberhasilan Usaha Koperasi Kelompok Tani Sari Rejeki Desa Pulosari Kecamatan Kebakkramat Kabupaten Karanganyar. Skripsi Fakultas Ekonomi Universitas Negeri Semarang. Diakses 4 Juli 2019. Pukul 14.00 .

Gemina, Dwi. 2017. Ekonomi Koperasi. Edisi 1. Bogor: Universitas Djuanda.

Gemina, Dwi, Samsuri dan Indra Cahya Kusuma. 2013. Keunggulan Bersaing Koperasi Berkaitan Dengan Penerapan Intellectual Capital, Manajemen Keanggotaan, Dan Partisipasi Anggota
Pada Koperasi Kota Bogor, JMK ISSN 1411-1438. Vol. 15, No 2. Hal. 191-204.

Hasibuan, Melayu. 2012. Manajemen Sumber Daya Manusia. Edisi 4. Jakarta: PT. Bumi Aska.

Hanel, Alfred. 2005. Organisasi Koperasi. Edisi 1. Yogyakarta: Graha Ilmu.

Hendar, Kusnandi. 2005. Ekonomi Koperasi. Edisi 2. Lembaga Jakarta: Penerbit FE Universitas Indonesia.

Husein, Umar. 2007. Metode Penelitian Untuk Skripsi Dan Tesis Bisnis. Jakarta: PT. Grafindo Persada.

Indah, Yovita. 2015. Pengaruh Partisipasi Anggota Dan Lingkungan Usaha Terhadap Keberhasilan Inti Kapur Desa Glodogan Kecamatan Kelaten Kabupaten Klaten. Skripsi. Program Studi Pendidikan Ekonomi. Universitas Negeri. Yogyakarta. Diakses 7 Juli 2019. Pukul 17.00

Ismail. 2005. Pengaruh Partisipasi Anggota Dan Manajemen Terhadap Keberhasilan Usaha Koperasi Karyawan Simpan Pinjam di Kota Batam. TESIS Pascasarjana, Studi Ilmu Manajemen. Universitas Erlangga Surabaya. Diakses 7 Juli 2019. Pukul 15.00. http://lib.unair.ac.id.

Khoriah, Nurani. 2016. Pengaruh Partisipasi Terhadap Keberhasilan Koperasi Dharma Khatulistiwa PDAM Kota Pontianak. Jurnal JEJAK Agustus. Vol 2, No 1. Hal. 28-42.

Khasan Setiaji. 2009. Pengaruh Partisipasi Anggota Dan Lingkungan Usaha Terhadap Keberhasilan Koperasi Pegawai Republik Indonesia (KPRI) Kapas Kecamatan Susukan Kabupaten Banjarnegara. Jurnal JEJAK, Vol. 2, No. 1, Maret 2009. Hal. 22-28 
Ketut Rantau. 2002. Pengaruh Partisipasi Anggota, Kualitas Pengelola, Kualitas Pengurus, Dan Peranan Pemerintah Terhadap Keberhasilan Usaha Koperasi. (Kasus KUD Di Kabupaten Buleleng Bali). SOCA: Jurnal Sosial Ekonomi Pertanian. Hal 1-10.

Mangkunegara. 2012. Manajemen Sumber Daya Manusia. Bandung: Rosdakarya.

Meilani, Ismulyaty. 2002, Hubungan Antara Faktor Anggota Dan Partisipasi Terhadap Keberhasilan Usaha Koperasi Dilembaga Penelitian Dikabupaten Bogor. Jurnal JEJAK April, Vol 2, No 1. Hal 33-42.

Ropke, Jochen. 2003. Ekonomi Koperasi Teori Dan Manajemen. Jakarta: Selemba Empat.

Setiaji, Khasan. 2009. Pengaruh Partisipasi Anggota Dan Lingkungan Usaha Terhadap Keberhasilan Koperasi Pegawai Republik Indonesia (KPRI) Kapan Kecamatan Susukan Kabupaten Banjarnegara. Jurnal JEJAK Universitas Negri Semarang. Vol. 2, No. 1, Hal. 2231.

Septiansyah, Agit dam Sri Harini. 2018. Pengaruh Motivasi Anggota, Manajemen Keanggotaan, Dan Partisipais Anggota Terhadap Keberhasilan Usaha Koperasi Wanita Dikabupaten Subang. Jurnal Visionida Universitas Djuanda Bogor. ISSN 18111822. Vol. 14, No 1. Hal. 23-34.
Subandi. 2017. Ekonomi Koperasi (Teori Dan Praktek). Bandung: Alfabeta.

Sugiyono. 2017. Statistika Untuk Penelitian. Bandung: Alfabeta.

Sugiyono. 2016. Metode Penelitian Kuantitatif, Kualitatif dan R\&D. Bandung: Alfabeta.

Suryana. 2006. Kewirausahaan. Jakarta: Selemba Empat.

Undang-Undang. Republik Indonesia Nomor 25 Tahun 1992 Tentang Perkoperasian.

Ponika, Tya. 2011. Pengaruh Partisipasi Anggota Dan Kemampuan Menejerial Pengurus Terhadap Keberhasilan Usaha KPRI Dwi Eksa Kecamatan Jepon Kabupaten Blor. Skripsi UNESS. Vol 3, No 2. September 2011. Hal 28-41.

Widodo, Sri. 2008. Pengaruh Komunikasi Dan Partisipasi Anggota Terhadap Keberhasilan Koperasi Unit Desa Melati. Skripsi Sarjana, Fakultas Ekonomi AKMENIKA UPY. Yogyakarta. Vol 17, No. 2. April 2008, Hal. 122-131. 